http://jurnal.fkip-uwgm.ac.id/index.php/Script

Script Journal: Journal of Linguistic and English Teaching

P-ISSN: 2477-1880; E-ISSN: 2502-6623

April 2017, Vol. 2 No. 1

\begin{tabular}{|r|c|c|}
\hline Received: April 2017 & Accepted: April 2017 & Published: April 2017 \\
\hline \hline Article DOI: http://dx.doi.org/10.24903/sj.v2i1.77 \\
\hline
\end{tabular}

\title{
Teacher's Role in Managing the Class during Teaching and Learning Process
}

Ignatius Rindu

Widya Gama Mahakam Samarinda University ignasiusrindu@gmail.com

Ariyanti

Widya Gama Mahakam Samarinda University ariyanti.muflihin@gmail.com

\begin{abstract}
The purpose of this research is to investigate teacher's roles which used by the English teacher in managing the class during the teaching and learning process at SMP Advent Samarinda. The research methodology used is descriptive design with qualitative approach which is aimed to describe the real situation in the field. In collecting the data, the researcher used questionnaires, observation sheet, field note and interview guide as the instruments. Moreover, the research subject is an English teacher who teaches at seventh and eighth grades of SMP Advent Samarinda. The result of the research is the teacher runs nine roles in they are as a controller, an assessor, an organizer/manager, a prompter/motivator, participant, a resource/informer, a facilitator, a demonstrator, and as a guide. There are roles which are preeminent which most applied by the teacher such as teacher as a controller and teacher as an assessor. It is shown by the result of students' respond in the questionnaire, restrictive questions; $77 \%$ and $68 \%$ and free answer; $68 \%$ and $100 \%$, which also found in the time the researcher did the observation. On the contrary, the teacher's roles as a prompter and as a resource have not been played maximally by the teacher.
\end{abstract}

Key Words: teacher's role, classroom management, english teaching and learning 


\section{INTRODUCTION}

It is universally recognized that teacher is a backbone of any educational system because knowledge is transferred from the teachers to be taught. Every country is giving a prime importance to the quality of teachers and national policies have been influenced by the growing realization that teachers have a key role to play in determining the quality of output of educational institutions. Even the modern technology has its own important roles in supporting the educational system; teacher is still the vital element in the teaching and learning process.

Teacher is a person who teaches, especially in a school. It is universally recognized that the teacher is the key person in an education system. She/he enjoys the high esteem and prestigious status sometimes denied to kings and emperors and he/she plays pivotal role. Around him, whole system of education revolves. Nowadays, teacher is so much needed in order to develop education's quality. According to Harmer (1990), there are metaphors to describe what teachers do; sometimes they are like actors because they are always on the stages. Others think they are like orchestral conductors because they direct conversation and set the pace and tone. In other words, teacher is a person who is trusted to educate the young generation to be a well-educated person. Being a teacher is not as easy as what people think. Teacher should know how to teach and manage their students in the classroom. In addition, teacher has a significant role in teaching the students.

Furthermore, Richards \& Rodgers (2014) state that 'Role' refers to the part that learners and teachers are expected to play in carrying out learning tasks as well as the social and interpersonal relationships between the participants. In attempting to determine a problem language, the teacher has some roles. A good teacher should have a capacity to perform his roles depend on different circumstances effectively. According to Harmer (1990), a teacher has six roles in managing a class, they are controller, assessor, organizer, prompter, participant, and resource. Additionally, Sanjaya (2007) also states that teacher has six roles in managing a class during teaching and learning process, they are teacher as a learning source, facilitator, manager, demonstrator, guide, and motivator.

However, whole elements that the researchers try to figure out are all about classroom management which the management itself refers to skill in the organization and presentation of lessons in such a way that all pupils are actively engaged in learning. This requires an ability to analyze the different elements and phases of a lesson, to select and deliver appropriate material and to reduce sources of friction. Moreover, a good management in a 
classroom can help students to reduce their levels of stress. Teachers can also build up their students' and their own self-management and learning skills in the classroom. Smith and Lastleth (2002) point out four rules in classroom management. The first is "get them in" which means the way teachers start a meeting or a class. This rule consists of greeting, Seating and starting. The second rule is "get them out" which means the way how teachers end a meeting or a class. This rule consists of concluding and dismissing. The third rule is "get on with it" which means the main part of the lesson the nature of its content and the manner of its presentation and the fourth rule is "get on with them" which means teachers develop good personal relationship with their students.

To create a succeed education, a good classroom management will be so much needed, because by applying this, a teacher can control, organize, assess and prompt a class well. Based on the fact that the role of a teacher in managing classroom is needed by the entire teacher, the researchers would like to find out the teacher's roles in managing the class during the English teaching and learning process in SMP Advent Samarinda.

\section{METHODOLOGY}

The design of this research is descriptive design with qualitative approach. Referring to Quenn (1990), the qualitative approach has some characteristics, those are: (1) qualitative research has the natural setting as the direct source of data and the researcher is the key instrument; (2) qualitative research is descriptive; (3) qualitative researchers are concerned with the process rather than simply with outcomes or products; (4) qualitative researchers tend to analyze their data inductively; and (5) "Meaning" is of essential concern to the qualitative approach. Additionally, Suryabrata (2003) says, literally, descriptive study is a research to make a description about situation or events. In this sense, descriptive study is an accumulation of basic data merely in a descriptive way. It is not necessary to test its hypothesis, to make prediction or to get meaning and implication.

Regarding with research instruments that the researchers use, firstly, the researchers are the key instruments. In this case, the researchers have some functions, such as; determine the focus of the research, select some information as the source of the data, assesses the data quality, analyze the data, and conclude of the findings (Sugiono, 2009). Secondly, the researchers used questionnaires which were given to the students to get students' ideas about the roles of the teacher in managing the class during the teaching and learning process. There were two kinds of questionnaire which were be used, they were free answer and multiple choice. In this case, questionnaire is a set of questions deal with a single topic which is 
related one another. This is used for investigating a problem which influences people. The questionnaire should be answered by the subject distributing to the subject in order to get any answers, responses, or ideas which is needed (Kartono, 2009).

Furthermore, the third research instrument that was used by the researchers was observation sheet to collect the data of the teacher's roles in managing the class during the teaching and learning process. The main aspect that the researchers focused on was the teacher's roles in managing the class which are applied during the teaching and learning process. Furthermore, the statements in observations sheet are the combination of the theory of Harmer and Sanjaya. In addition, the researchers also used field note to write activities which happened in the class during the researchers do the observation, such as the situation of the class and the activities during the teaching and learning process. Lastly, the researchers also had an interview. In this case, the researchers directly had some questions with the teacher who was the subject of this study.

Moreover, to collect the data, the researchers act as passive observers where they did not participate to any single activity during the lesson. Related to how the researchers analyze the data, the researchers used a flow model of data management and analysis methods which proposed by (Miles \& Huberman, 1994). Specifically, the data analysis contains three linked sub processes: data reduction, data display, and data conclusion drawing/verification.

\section{FINDINGS}

a. The Result from Restrictive Questionnaire

\begin{tabular}{|c|c|c|c|c|}
\hline Question & $\underset{\frac{\pi}{2}}{\stackrel{n}{2}} \widehat{d}$ & $\frac{\Xi}{0} \underset{0}{0}$ & 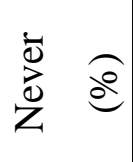 & 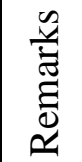 \\
\hline $\begin{array}{l}\text { 1. Does the teacher control the language which } \\
\text { used by the students in the class? } \\
\text { 2. Does the teacher control the students' } \\
\text { behavior in the class? } \\
\text { 3. Does the teacher asses the students' } \\
\text { assignment? } \\
\text { 4. Does the teacher check the students' } \\
\text { mistakes in doing the assignment? }\end{array}$ & $\begin{array}{c}17 \\
(77 \%) \\
15 \\
(68 \%) \\
20 \\
(91 \%) \\
16 \\
(73 \%)\end{array}$ & $\begin{array}{c}5 \\
(23 \%) \\
7 \\
(32 \%) \\
2(9 \%) \\
6 \\
(27 \%)\end{array}$ & - & \\
\hline
\end{tabular}




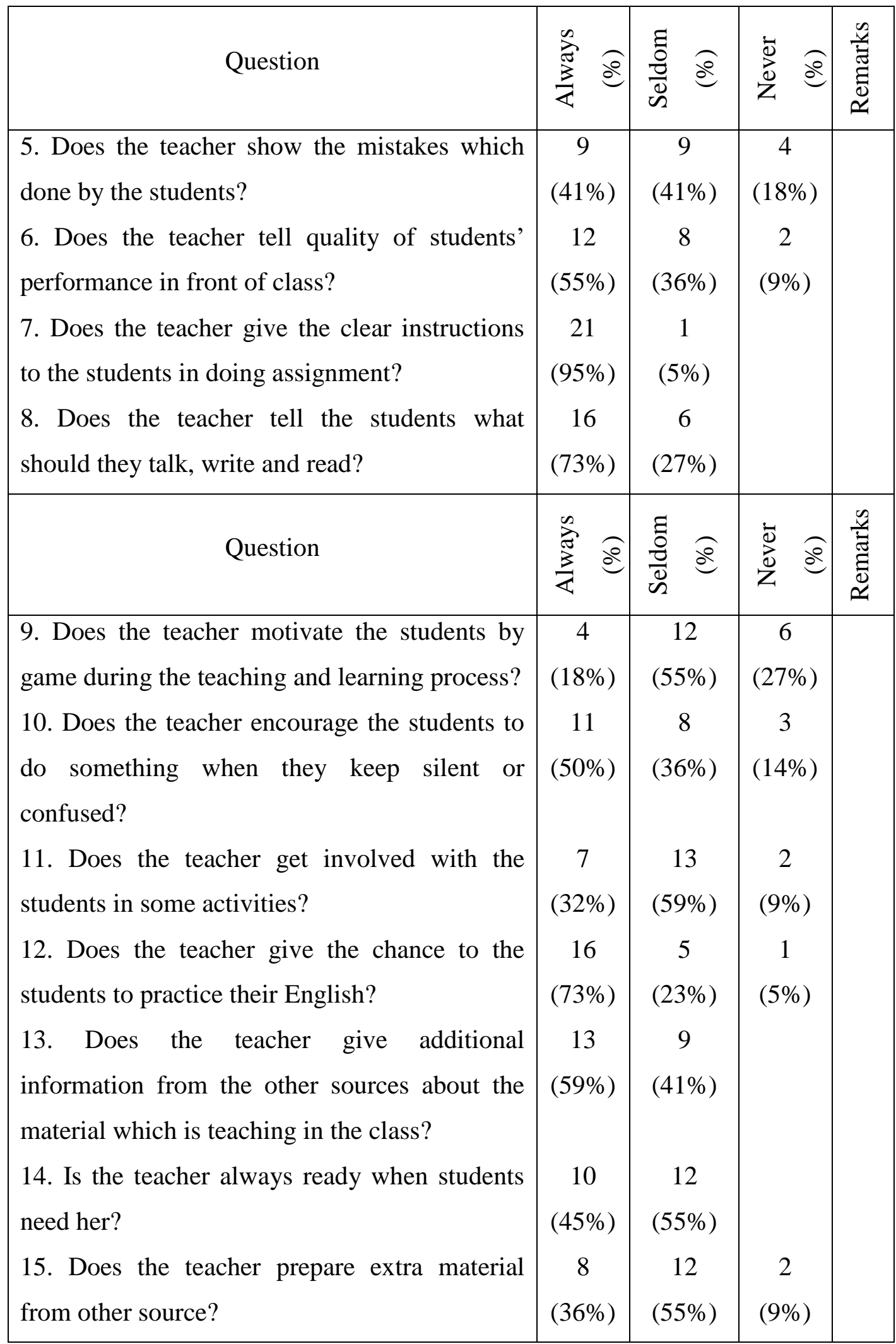

\section{Table 1 The result table}

\section{b. The Result from Questionnaire with Free Answer}

This questionnaire consists of twelve questions. Here the students were asked to deliver their opinions about the teacher's role. 
Question number one, "What does your teacher do in controlling the students" language and behavior in the class?" the answers are so various. There are 14 students or $63 \%$ answered that the teacher usually advises the students. 3 students or $14 \%$ answered that the teacher is usually firm but not so always. 2 students or $9 \%$ answered that the teacher usually warns the students. The rest of three students or $14 \%$ had the answer that the teacher prohibits, punishes and even fines them.

Question number two "How does your teacher guide you in the teaching and learning process?" there are 11 students or $50 \%$ said that the teacher is good in guiding them. They said that the teacher usually give guidance and explanation before they do some activities. 4 students or $18 \%$ answered that the teacher usually guides them by inviting them to read the bible. 4 others or $18 \%$ students answered that the teacher usually guides them patiently. 3 students or $14 \%$ had the opposite answer with their friends. They said that the teacher is usual in guide them sometimes the feel bored.

Question number three "How does your teacher assess the students' assignment?" the first 6 students or $27 \%$ answered that the teacher usually assesses their assignment by seeing their ability. The second 6 students or $27 \%$ answered that the teacher is so accurately. They said that she assesses their assignment by seeing their how active they are, and also their tidiness in doing assignment. 8 students or $36 \%$ answered that the teacher usually invites them to check or assess the assignment together so they can discuss it together but sometimes the teacher does it alone. The rest of 2 students or 9\% answered that in assessing the assignment, the teacher usually forms them into groups.

Question number four which asks about "The style and the way of teacher in teaching", 16 students or $73 \%$ answered that the teacher is usually serious, firm and also discipline but actually in the whole teaching, she is also fun. They said that teacher often makes some jokes and makes the class becomes alive. 4 students or $18 \%$ answered that ways which are usually used by the teacher is good. They said that the teacher is so patient. In starting the class, the teacher usually tells them the aim in learning a topic or a material and also what things they should remember about the topic. Furthermore, they said that the teacher usually explains a material slowly an in the soft voice so this makes them understand with the explanation. They added if there are students who still do not understand with her explanation, she will repeat it. In the other hand, 2 students or $9 \%$ answered that the style of the teacher in teaching is is general and sometimes it seems borring.

Question number five "How does your teacher start the class?" 16 students or 73\% answered that the teacher usually starts the class by inviting all of the students to pray. And 
after that the teacher greets the students and asks about their condition at the day. 4 students or $18 \%$ said that, after praying together, the teacher sometimes asks the students about their readiness to join the class. The rest of 2 students or $9 \%$ answered that after praying, the teacher sometimes talks about the material directly. Sometimes, the teacher offers some question to the students as a warm up to direct them to topic that will be discussed at the day.

In answering question number six "How does your teacher finish the class?". All students or $100 \%$ answered that the teacher usually finishes the class by praying together and then teacher greets her students. Besides answered that, they also had additional answer. Two students or $9 \%$ added that teacher usually addresses her thank and appreciates the students because of joining her class. 7 of them or $32 \%$ added that sometimes the teacher gives some review and conclusion about the material which has been discussed. Furthermore, the teacher also gives the students homework.

Question number seven which asks about “The teacher's actions when she sees that there are students who have not understand the material well", 14 students or $63 \%$ said that the teacher usually repeat her explanation to all students. The teacher usually explains the material slowly to the students. 5 students or $23 \%$ answered that the teacher usually asks the students if there is something that they do not understand. Sometimes, the teacher tests the students by offering some questions. 5 students or $23 \%$ answered that sometimes teacher does not ask any question to the students. The teacher usually asks the students to learn by themselves at home. 3 students or $14 \%$ answered that sometimes the teacher gets mad with students if they are still confused although the teacher has explained a material more than three times.

In answering question number eight which asks about "The supported media which is usually used by the teacher in teaching", all of the students or $100 \%$ said that the teacher usually uses LCD Projector but sometimes teacher also brings some interesting pictures and other stuff or media which related with the topic. For example, in using LCD Projector, the teacher usually teaches the students by displaying material in slides in the power point program and the teacher often shows some pictures or even assignment by LCD.

In answering question number nine "How does your teacher motivate the students?"13 students or 59\% said that the teacher often encourages them to study by saying motivated statements. Among them, there are 5 students added that sometimes the teacher tells some stories and even the story which is experienced by her to motivate the students. 5 students or $23 \%$ answered that the teacher usually invites the students to watch a funny movie to entertain the students and to refresh them. 4 students or $18 \%$ said that, sometimes the 
teacher gives some reward or gifts for the students who are diligent in doing assignment in the class or homework.

In answering question number ten which asks about "The way of the teacher in giving the instructions in doing something in the class?" 16 students or $73 \%$ said that the teacher usually gives the instruction clearly and she usually starts by giving example first. 2 students or $9 \%$ said that, in explaining something, the teacher usually tells it step by steps repeatedly. And if there are mistakes made by the students, the teacher will fix them. The rest 4 students or $18 \%$ also added that in the time of doing assignment, the teacher usually asks them firmly.

Question number eleven which asks about "The way of the teacher in handling the students who are not brave to get involved actively in the class?" 6 students or $27 \%$ said that the teacher usually persuades them to involve. 9 students or $41 \%$ answered that the teacher usually encourages and support the students to be brave. 1 student gave the example based on his experience that he once called by the teacher and they had a chat about his problem at the break time. He also said that, the teacher also did it with other students. In the other hand, 4 students or $18 \%$ said that in handling those students who are not active enough in the class, sometimes teacher gives extra assignment to fulfill their score. 3 students or $14 \%$ answered that the teacher usually warns those students who are not brave enough and sometimes the teacher gets mad.

In answering question number twelve which asks about "The way of the teacher in serving the students when they find problems such as difficultness in comprehending a material?" 11 of them or $50 \%$ said that the teacher usually explains it again till the students understand the material. 4 students or $18 \%$ answered that sometimes the teacher has some approaches with those students to know what problems they have. 5 students or $23 \%$ answered that the teacher also usually advises the students to study hard at home and always do the homework which given to them. In the other hand, there are 2 students or $9 \%$ also said that sometimes the teacher gets mad with those students.

\section{c. Data Result from Observation Sheet and Field Note}

In doing research, the researchrs did the observation and made the field note in the same time. In the first day, the researchers did observation in class seven. Here, the researchers saw that the teacher played some roles in teaching. The first was as a controller. The researchers saw the teacher controlled the students' behavior, attitude and also the way they communicated during the teaching and learning process. The researchers saw the teacher advised the students when they say some improper words in the class. 
At the beginning, in starting the class, the researchers saw that the teacher played the role as a guide. Here, she invited her students to pray and after that she gave the morning motivation before starting the teaching and learning process. This is the habit which should be done by every teacher who teaches in the first subject. In a few moments after that, the writer saw the teacher played the role as an organizer. Here, the teacher told the students what they are going to learn at that day. This also happened when the teacher gave the assignment, she firstly gave clear instruction and she made sure that the students were ready to do the assignment. The teacher also gave examples before she gave the assignment. During doing the assignment, she walked around the class and to see her students work. Next, when they checked and discussed the answer together, the teacher let the students answer the questions. She also listened to the idea or opinion from the students. In the last session, the teacher had last review about the material that had been learnt. At the time of the end of the class, teacher gave short review to strengthen their mind about the material which had been taught.

In the second day, the researchers did the observation in class eight. Here, the researchers got the same data. The teacher still played the same role as she did in the first day when she taught class seven such as a controller, a demonstrator, a guide and an organizer. The way of teaching which the teacher did in this class was same with the way of her teaching she did in the first observation. The only different thing which was done by the teacher in this was the writer use LCD in teaching. In this class, the researchers got a new role. Here, the researchers saw the teacher also played the role as a prompter. The researchers saw how the teacher supported the students during the teaching and learning process and especially at the time when the teacher gave assignment to the students. During the teaching and learning process, the situation of this class was alive. The researchers saw that the teacher sometimes threw some jokes to make the students laughed and happy.

In the third day, the researchers the researchers saw that the teacher still played the same role as she did in the two previous meeting. She still acted as a controller, a guide, a prompter, a participant, an organizer and an assessor. Although the way the teacher did teaching was somewhat different with those previous meeting, but she still showed and played those roles like at the previous meetings. In that day she more often had some jokes so that day the class was so crowded.

In the fourth day, when the researchers did the observation in class eight, the researchers still saw that the teacher played the same role as she did in the three previous meeting. She still acted as a controller, a guide, a prompter, a participant, an organizer and an 
assessor. There was no more roles was seen by the researchers, but they still joined the class untill the end of the teaching and learning process.

In the fifth day, the researchers decided to still have the observation. In that day, the researchers did the observation as the third observation in class seven. During the teaching and learning process, the researchers saw that the teacher still played the same role as she did in some previous meetings. There was no more or additional role that the researchers saw acted by the teacher. Based on this reason, the researchers then decided to stop the observation in the fifth meeting.

\section{d. Data Result from Interview}

In doing the interview, the researchers had some questions to address to the teacher to dig and find out what roles which she had applied during teaching and learning process. The teacher also shared her experiences that she experienced during she taught the students in the class to the writer.

In answering question number one which asked about things which had been done in managing the class and what the impact was, the teacher gave statement that the teacher usually controls the class which means that disciplinize the class by creating a confortable and safe situation before starting the class. She added that by doing that she gives the chance to the students to prepare everything and it works and brings good impacts.

By doing that, periodically, students will also understand and know their teacher's character, habit, will and what should they behave when they face and meet with the teacher. Furthermore, she also said that she usually recognize the situation and condition of a class. She also creates a live class so the students will not feel bored joining her class. For this, to avoid a monotonous class, she usually uses some interesting media to attract the students' attention.

Question number two asked about how the teacher controls the behavior and language used by the students in the class. Here, the teacher stated that she usually mingles with the students to see and observe the students' behavior and the way they communicate. If she finds those things, she will call and or reprimand the student in good ways so she will not make the students get offended.

Question number three asked about how she shows the students' mistakes in doing assignment and helps them to realize and understand the mistakes and also corrects them. The teacher also told that sometimes she finds that there are students who have not understood a material well although it has been explained for times. In facing that, the teacher usually tells their mistakes directly. After that, she usually invites them to discuss about the material. 
Related with that, she told that, sometimes there are students who are offended with those ways. In handling those students, she usually calls the students personally so the students can be guided well. She said that those ways really work.

Question number four asked about what she does first before giving assignment to the students. In answering this, the teacher told that she usually starts it by giving the explanation and usually follows by offering some simple questions. She added that, sometimes she finds students who are not brave to tell their confusion about a material at the time and they will tell it after class.

Question number five asked about what the teacher does to create a live and confortable class during the teaching and learning process. The teacher answered that she usually gives some quizzes with the rewards. This makes them to be enthusiastic. They will compete each other to get the reward. By doing that, the teacher makes the students to be refocused joining her class.

Question number six asked about the supported media which had been used by the teacher in teaching. The teacher gave statement that she usually uses laptop, LCD Projector and sometimes she brings some interesting pictures. She prepares the media based on her own initiative. In this case, she added that actually the school also prepares some media to make the teaching and learning process easier and more interesting.

Question number seven asked about what the teacher does when she finds students' questions which cannot be answered at the time. In answering this question, she stated that sometimes she tells honestly to her students if she has not found or even she does not know the answer of the students' questions. She also promises to the students that the questions will be her homework and she will answer those in the next meeting. She added, to solve the problem, sometimes she invites the students to discuss and find out the answer or the solution together with her students.

Question number eight asked about what the teacher does in order to make her students understand a material well in a class. The teacher said that she usually explain a material slowly and detail. Sometimes, she repeats her explanation to make sure that the students understand it. After that she usually gives some brief tests to examine the students comprehension and understanding about the material.

Question number nine asked about the teacher actions in handling the students so they can grow well according to their potential, talent and interest. In answering this question, the teacher told that the first thing she does is she recognizes the students' character. After that, she guides them to be better according to their potential, talent and interest in the 
teaching and learning process related and according to the material which is taught. The teacher also said that, in this case, she values every potential, talent and interest which own by each student in the class.

\section{DISCUSSION}

After finding the teacher's roles which have been applied by the English teacher in managing the class during the teaching and learning process in SMP Advent Samarinda, the researchers would like to present the discussion as follows:

\section{a. The teacher as a controller}

The teacher as a controller is teacher who controls the whole activity in the class during the teaching and learning activity, including the language and students' behavior which happend in the classroom.

Based on the data and the real condition that had been found during the research about the role of a teacher as a controller, the teacher who teaches English in SMP Advent Samarinda (Class VII and Class VIII) has fulfilled her role as a controller in the classroom. It's proved by the result of quesionnaires, observation, field not and interview guide.

In the resctrictive questionnaire; the answer of question number one shows that $77 \%$ students said that the teacher always advices them and $23 \%$ said seldom. In question number two of restrictive questionnaire, $68 \%$ students answered the teacher always controls the language, and 32\% said seldom. In the free answer, question number one; $86 \%$ students told that the teacher always advices and warn the students firmly and 14\% students even told that in controlling the students, the teacher sometimes prohibits, gives punisment and fines them.

In the field note and observation sheet. In every meeting which has been observated, it was seen that the teacher always controls the students' behavior, the language and also advices the students during the teaching.

In the interview guide. In the first and second question, the teacher gave statement that she usually controls her students and straighten up the class by creating peace in the begining of the class. From all the findings data, it is clear that the teacher controls the students in teaching and learning process.

\section{b. The teacher as an assessor}

The teacher as an assessor is teacher who assesses the activity of students during the teaching and learning process. As the result of the research that found in the field that the 
English teacher in SMP Advent Samarinda (Class VII and Class VIII) has played the role well in assessing the students. It can be proved from the questionaire; in question number three of restrictve questionnaire, $91 \%$ students said that the teacher always assesses their assignments and 9\% students said that the teacher seldom does that. In question number four from the restrictive questionnaire, $73 \%$ said that the teacher always checks their mistakes, and the rest students or $27 \%$ said seldom. It also shown in question number five, where $41 \%$ students said that the teacher always shows the mistakes, $41 \%$ students said seldom and $8 \%$ said never. In question number six of restrictive questionnaire, $55 \%$ assesses the students' performance by telling them directly. $36 \%$ said that the teacher seldom does that, and 9\% said that the teacher never does that. In question number three of free answer questionnaire, all students or $100 \%$ said that the teacher assesses their assignment in two ways, such as teacher assesses the assignment by herself accurately and she does it together with the students.

In the field note and observation sheet, it was seen that the teacher together with the students discuss and assess the assignment. In the interview guide, based the question number 3, the teacher says by her self that she assesses and does the correction for the mistakes and then discusses them. From all the data above, it can be stated that the teacher is the assessor. She corrects, assesses and discusses the students' mistakes.

\section{c. The teacher as an organizer/manager}

The teacher as organizer/manager is teacher who manages all the elements that involved in teaching and learning activity. In the question number seven of restrictive questionnaire, 95\% students said that the teacher always gives clear instructions before the students do an assignment. 5\% students said that the teacher seldom does that. In the question number eight of restrictive questionnaire, $73 \%$ students said that the teacher always tells them what should they talk, write and read, 27\% students said that the teacher seldom does it. In question number ten of free questionnaire, all students or 100\% said that the teacher usually gives clear instruction and she usually starts it by giving example.

In the field note and observation sheet, it was seen that the teacher told the students what are going to learn, the teacher gave the clear instruction and made sure that the students are ready to do the assignment. In the interview, based on the question number 4, the teacher stated that she usually gives the explanation first about the assignment and also give some simple questions. Based on the data above, the teacher is a an organizer. She gives clear instruction to the students. 


\section{d. The teacher as a prompter/motivator}

The teacher as prompter/motivator is a teacher who is able to give encouragement or motivation to the students in teaching and learning process. In question number nine of restrictive questionnaire, $18 \%$ students answered that the teacher always motivates them, $55 \%$ said that the teacher seldom motivates them and $27 \%$ said that the teacher never motivates them. In question number ten of restrictive questionnaire, 50\% answered that the teacher always encourages them when they keep silent or confused, 36\% answered that the teacher seldom does that and $14 \%$ said that the teacher never does that. In quetion number nine of free quetionnaire, all the students or $100 \%$ answered that the teacher always motivates them. They said that the teacher usually does that by giving some motivated statements, telling stories, watching funny movie and also giving some rewards for students. In question number twelve, $18 \%$ students say that the teacher motivates them in order to study harder. $14 \%$ students say that the teacher sometimes scolds them.

In the field note and observation sheet, it was seen that the teacher also did some jokes. In the interview, in the first question, the teacher gave statement that in starting teaching, she usually sees situation and the condition first and during teaching she usually creates more alive situation. It is also shown by teacher's statement in answering question number five that, she gives some quizzes with the rewards or gift to support and attracts the students' attention.

Based on the data above, the teacher is a prompter/motivator where she usually motivates the students by giving the encouragement statement and does things that can attract the students attention and rise up the students passion in study.

\section{e. The teacher as a participant}

The teacher as participant means that the teacher participates in some activities in the class during the teaching and learning process. In the question number eleven of restrictive questionniare, $32 \%$ students answered that the teacher always gets involved with the students in activities. 59\% students says that the teacher seldom does that and 9\% students answer that the teacher never does that.

In the field note and observation sheet, it is seen that the teacher gives the chance to the students to answer the questions and deliver their ideas or opinion. She also listens to the students' opinion. In the interview, in the question number two, the teacher states that she mingles with the student and also participates in activities as a students'partner. In question number two, she stated that she together with the students find out the answer. Based on the data above, it can be stated that the teacher is a participant where she gets 
involved, give the students chance, listens to the students opinion and becomes students' partner.

\section{f. The teacher as a resource/informer}

The teacher as resource/informer is a teacher who becomes the resource of information relate to the development of knowledge and technology. Furthermore, the teacher also should be ready in helping the students when he or she is needed.

In the restrictive questionnaire question number thirteen, 13 students or 59\% answer that the teacher always gives and prepares additional information from other source whereas 9 students or $41 \%$ answer that the teacher seldom does it. It is also stated in question number fourteen in restrictive questionnaire where 10 students or $45 \%$ answer that the teacher is always ready when they need her and 12 students answer that the teacher seldom does that. In question number fifteen of restrictive question, 8 students or $36 \%$ answer that the teacher always prepares extra material from other sources, 12 students or 55\% answer "seldom" and the rest of 2 students or $9 \%$ answer "never". In the question number twelve of free questionnaire, $68 \%$ students give answer that the teacher is always ready helping the students when they need her. The teacher will explain again till they understand and having individual approach to the students during the class.

On the interview in the question number seven, the teacher states honestly that she will give the answer in the next meeting when the students ask for an answer or information and she has not got any idea. Based on the findings data, it can be stated that the teacher is an infromer/resource where she is always ready to her students when they need her. But sometimes she postpones it.

\section{g. The teacher as a facilitator}

The teacher as facilitator means that the teacher gives good services to the students such as giving the chance for each student in doing activities and also prepares facilities to support the teaching and learning activity. In other words, the teacher can ease the students to study.

In question number twelve of restrictive question, 16 students or $73 \%$ answer that the teacher always gives the chance to the students to practice their English, 5 students or $23 \%$ answer seldom and 1 student or 5\% answer never. In question number eight of free qestionnaire, all the students or 100\% say that the teacher uses media (LCD Projector) in showing and explaining the material in her teaching.

In the field note and observation sheet, it is seen on the second day that the teacher uses a media to support her teaching. It is also supported by the admision of the teacher in 
the interview in question number one and number six. There, the teacher says that in teaching, she usually uses some media such as laptop, LCD projector and also some interesting pictures to avoid a boredom class. Based on the data above, it can be stated that the teachr as a facilitator where she usually uses supported media which help the students to understand the material which is taught in the teaching and learning process.

\section{h. The teacher as a demonstrator}

The teacher as a demonstrator means that, the teacher shows everything well. Here, this can be divided into two things. The first is connected with the attitudes and behavior. The second is connected with how the teacher delivers explanation or gives instructions in teaching.

In question number four of free questionnaire, $100 \%$ students say that the teacher teaches them seriously, firmly and discipline. In other side, the teacher is also fun. The jokes she makes in the process of the study creates the class more alive and it is supported with the other things such as good teaching, patient, explain softly and gently, and all of this makes the students understand the material easier.

In the field note and observation sheet, it is seen that the teacher usually gives the warm up at the begining of the class and also gives the review at the end of the class. It is also shown in the time when she delivers the material where she gives clear explanation. Based on the data above, it can be stated that the teacher is a demonstrator where she always conducted teaching well and discipline. She also knows how to make a more alive class.

\section{i. The teacher as a guide}

The teacher as a guide means that the teacher directs and keeps the students to the good things and directions. In question number eleven of free questionnaire, $100 \%$ students state that the teacher guides them by persuading and them to get involved, encouraging and or directing them. It is supported with the personal experiences of one of the students which once sumonned by the teacher and they talked what is the problem which made him to be inactive in the class. Another students also adds it is for all students with the same problem. The teacher will also give exra assignment to inactive students. The teacher often gets impatien and even gets mad.

In the field note and observation sheet, it is show that the teacher usually invites and lead the students pray. After that she also gives morning reflection to the class before starting the class. In the interview guide question number three, the teacher states that she calls the students to be guided well when there are students who are easy to get offended. 
In question number nine, the teacher states that the teacher drags the students based on their interest to be better. Based on the data above, the teacher is a guide where she directs them to be better according with their interest and potential during the teaching and learning process.

\section{CONCLUSION}

Based on the findings and the discussion as well as the purpose of the study, it can be noted that generally the English teacher who teaches in SMP Advent samarinda applies all the nine roles in managing the class during the teaching and learning process but there are roles which are preeminent which most applied by the teacher. Those preeminent roles are mostly found in the time when the teacher does teaching (this is found at the time the researcher does the observation).

The teacher's roles which are most often used and applied by the English teacher in SMP Advent in managing the classroom (class VII and VIII) are teacher as a controller and teacher as an assessor. The teacher's roles which are often used and applied teacher in SMP Advent in managing the classroom (class VII and VIII) are teacher as an organizer, as a facilitator, as a participant, as a demonstrator and as a guide. Meanwhile the teacher's roles which are seldom used or have not been applied maximal by the teacher in SMP Advent in managing the classroom (class VII and VIII) are teacher as a prompter and as a resource.

\section{BIBLIOGRAPHY}

Harmer, J. (1990). The Practice of English Language Teaching. Twelfth Impression. New York: Longman Inc.

Kartono, K. (2009). Pengantar Metodologi Riset Sosial. Bandung: Mandar Maju.

Miles, M. B., \& Huberman, A. M. (1994). Qualitative Data Analysis (2nd ed.). California: Sage Publications.

Quenn, M. (1990). Qualitative Evaluation and Research Methods. California: Saga Publications.

Richards, J. C., \& Rodgers, T. S. (2014). Approaches and Methods in Language Teaching. Cambridge: Cambridge University Press.

Sanjaya, W. (2007). Strategi Pembelajaran (3rd ed.). Jakarta: Prenada Media Group.

Smith and Lastleth. (2002). Effective Classroom Management: A Teacher's Guide (2nd ed.). New York: Routledge. 
Sugiono, sugiono. (2009). Metode Penelitian Pendekatan Kuantitatif, Kualitatif dan $R \& D$. Bandung: Alfabeta.

Suryabrata, S. (2003). Methodologi Penelitian. Jakarta: Raja Grafindo Persada. 